\title{
Political Parties and Monetary Commitments
}

\author{
William Bernhard \\ Department of Political Science \\ University of Illinois at Urbana-Champaign \\ Urbana, IL 61821 \\ Bernhard@uiuc.edu \\ Phone : 217 244-8413 \\ Fax : 217 244-5712 \\ David Leblang \\ Department of Political Science \\ University of Colorado \\ Boulder, CO 80309-0333 \\ Leblang@colorado.edu \\ Phone: 303 492-6812 \\ Fax: 303 492-0978
}

Word Count: 12,225 


\section{Affliation Page}

William Bernhard is Assistant Professor of Political Science at the University of Illinois at Urbana-Champaign, Urbana, IL 61821. Bernhard@uiuc.edu

David Leblang is Assistant Professor of Political Science at the University of Colorado-Boulder, Boulder, CO 80309-0333. Leblang@ colorado.edu 


\section{Acknowledgement Page:}

We thank Lawrence Broz, Bill Clark, Rob Franzese, Brian Gaines, Jim Granato, Torben Iversen, and Beth Simmons for helpful comments. We thank Dennis Quinn for sharing data. 


\begin{abstract}
Page
Political Parties and Monetary Commitments

William Bernhard

David Leblang

Increased levels of economic openness in the industrial democracies have heightened the potential for intra-party and intra-coalition policy conflicts, hurting the ability of parties to win and retain office. We argue that politicians can use monetary commitments to help manage these conflicts and improve cabinet durability. To determine the political value of these commitments, we test the effect of fixed exchange rates and central bank independence on cabinet durability using a set of 193 cabinets in 16 parliamentary democracies across the period 1972-1998. The results indicate that monetary commitments are associated with higher cabinet durability, particularly for coalition governments. We then use the results of our statistical models to generate expected cabinet durability under alternative institutional configurations. By comparing these expected values, we show that actual monetary reforms in the industrial democracies have helped (or at least not hurt) the ability of political parties to remain in office.
\end{abstract}


We argue that political parties will choose monetary institutions in order to help them win elections and retain office. Increased levels of economic openness in the industrial democracies have complicated the pursuit of office by altering the policy preferences of constituents and decreasing the ability of cabinet ministers to deliver promised economic outcomes. We contend that monetary commitments can help political parties manage diverse constituent interests, restore policy effectiveness, and, ultimately, maintain their position in office. Therefore, we expect that fixed exchange rates and central bank independence can improve cabinet durability, especially under conditions of economic openness.

In the first section, we discuss how fixed exchange rates and central bank independence can insulate cabinets from the political shocks of increased economic openness. To determine the political value of these commitments, we then test the effect of exchange rate commitments and central bank independence on cabinet durability in the second section. In the third section, we use the results of our statistical models to generate expected cabinet durability for the countries in our sample under alternative institutional configurations. By comparing the expected probabilities, we show that most monetary reforms have helped (or at least not hurt) expected cabinet durability.

\section{$\underline{\text { Economic Internationalization, Monetary Commitments, and Governance }}$}

Over the past 30 years, the economies of the industrial democracies have become increasingly integrated. ${ }^{1}$ Higher levels of economic openness have increased the potential for intra-party and intra-coalition conflicts over economic policy. In particular, changes in the patterns of electoral support for the main governing parties and decreases in the ability of cabinet ministers to deliver promised policy outcomes have hurt the ability of the main governing parties to win and retain office.

\footnotetext{
${ }^{1}$ Milner and Keohane 1996; Quinn and Inclan 1997; Goodman and Pauly 1993; Simmons 1999.
} 


\section{Changes in Constituent Demands}

Increased economic openness changes constituent interests over economic policy. ${ }^{2}$ Further, economic internationalization affects the relative influence of different sectors over economic policy. Owners of internationally mobile assets--in particular, capital—can threaten to withdraw those assets if they are dissatisfied with the government's policies. Therefore, politicians must respond to their demands if they wish to attract and retain these assets for their country, even if these sectors do not form part of the government's electoral coalition. ${ }^{3}$

These developments have altered the socio-economic coalitions underlying political parties in the industrial democracies over the past 20 years. ${ }^{4}$ There has been a diversification in the economic policy demands made by voters. New issues have become salient. ${ }^{5}$ New cleavages have emerged, reflecting divisions between exposed and sheltered sectors, manufacturing and service sectors, rising and declining industries, the private and the public sector, between owners of mobile and specific assets. ${ }^{6}$ The diversification of constituent preferences has increased the potential for intra-party and intra-coalition conflict over economic policy, making it more difficult for parties to attain and retain office.

2 Franseze 2000; Frieden 1991; Frieden and Rogowski 1996; Iversen 1999; Keohane and Milner 1996; Rogowski 1989.

${ }^{3}$ Frieden 1991; Maxfield 1997; Keohane and Milner 1996.

${ }^{4}$ For example, Pempel 1998.

${ }^{5}$ For example, Inglehart 1997.

${ }^{6}$ Iversen 1996; Rosenbluth 1996; Franzese 2002; Iversen 1999; Iversen and Cusak 2000. 


\section{Decreased Policy Effectiveness}

Since the 1970s, the ability of governments to deliver promised economic outcomes has also decreased substantially. The emergence of high public debt during the 1970s and early 1980s in many industrial democracies limited the flexibility of fiscal policy. ${ }^{7}$ As a result, government ministers faced a temptation to rely on monetary policy to manage the economy.

At the same time, however, established monetary policy choices no longer produced predictable outcomes. Prior to the 1970s, monetary policy reflected the idea of the Phillips Curve, which predicted a relatively stable trade-off between inflation and unemployment. In the 1970s, however, both theoretical critiques ${ }^{8}$ and empirical evidence-stagflation in the industrial democracies--undermined confidence in the Phillips Curve. As a consequence, it became less clear how monetary policy affected overall economic performance-and what policies policymakers should pursue. ${ }^{9}$

During this period, the industrial democracies also became more exposed to the international economy, exacerbating the problems of policy management. ${ }^{10}$ Openness exaggerated the economic and social consequences of policy actions. ${ }^{11}$ Advances in technology shortened the time lag between policy choices and policy outcomes. Policymakers, therefore, had to respond

${ }^{7}$ Franzese 2002; Roubini and Sachs 1989a, 1989b; Hallerberg and von Hagen 1999.

${ }^{8}$ Friedman 1968; Lucas 1972.

${ }^{9}$ Clarida, Gali, and Gertler 1999; Sargent 1999.

${ }^{10}$ Clark 1999; Oatley 1999; Clark and Hallerberg 2000; Simmons 1994.

${ }^{11}$ Frieden 1991; Franzese 2002. 
more quickly and more accurately to exogenous shocks in order to meet the demands of their constituents.

Decreased policy effectiveness hurt the ability of cabinet ministers to achieve promised outcomes-with predictable political consequences. Poor economic performance led to sharp electoral losses for incumbents. Parties that were in office during the stagflation of the 1970s were exceptionally hard hit, losing their reputation for capable policy management.

\section{Socio-Economic Change and Intra-Party Conflict}

The combination of diversified constituent demands and decreased policy effectiveness increased the possibility of intra-party conflict over economic policy during the 1980s and 1990s - conflicts that threatened the ability of the main governing parties to win and retain office. Indeed, intra-party conflicts occurred throughout the industrial democracies and across the ideological spectrum. In Left parties, traditional working-class constituents battled not only export interests, but also middle class post-materialists and public sector workers for control of party programs. ${ }^{12}$ In Germany, the Social Democratic-led government of the 1970s and early 1980s collapsed, in part, due to conflicts between moderates and trade unionists over the best response to the second oil shock. In the wake of defeat in 1979 elections, the British Labour party splintered, before pulling back toward the center in the 1990s. In France during the 1980s, Mitterrand's decision to pursue economic rigueur involved sweeping changes to the Socialists' constituent base, creating conflict and dissension within the party. ${ }^{13}$ In the United States,

12 Kitschelt 1994; Kitschelt 1999.

13 Frieden 1994; Loriaux 1991. 
Democratic party centrists and trade unionists have battled over trade and environmental issues. ${ }^{14}$ In Scandinavia, Social Democratic parties have faced constituents with increasingly divided interests. $^{15}$

Right parties face similar conflicts. The Italian Christian Democrats suffered internal battles over the best response to union militancy and the economic shocks of the 1970s and early 1980s. ${ }^{16}$ In Britain, policy conflicts between Tory Wets and radical free-market Thatcherites divided the Conservative party during the 1980s and 1990s. ${ }^{17}$ In Japan, economic openness contributed to conflicts between the Liberal Democratic party's main constituents-exportoriented industries favor more openness while small business and agriculture want to maintain protection. ${ }^{18}$ On both sides of the political spectrum, these intra-party conflicts made governance more difficult and shortened cabinet durability.

\section{Monetary Commitments}

Many studies contend that monetary commitments--a fixed exchange rate, participation in the European Monetary System, an independent central bank--exacerbate these intra-party conflicts by forcing politicians to pursue unpopular policies and, as a result, reduce cabinet durability even further. Instead, we argue that these monetary commitments can, under certain circumstances,

${ }^{14}$ Shoch 2000.

15 Iversen 1996.

${ }^{16}$ For example, Goodman 1992.

${ }^{17}$ For example, Hall 1986.

${ }^{18}$ Rosenbluth 1996. 
help prevent some intra-party and intra-coalition conflicts and, as a result, help extend cabinet durability. In particular, these institutions can help cabinet ministers balance the interests of constituents and legislators with diverse policy preferences and increase policy effectiveness.

Monetary institutions can help party leaders facilitate agreement and cooperation among parties and legislators with diverse policy preferences in a number of ways. First, monetary commitments provide information about the behavior of policymakers to party legislators, potential coalition partners, markets, and the public. This information can facilitate trust between the cabinet, party legislators, and potential coalition partners and, in turn, can increase cabinet durability. In a parliamentary system, parties delegate policy authority to the cabinet (i.e., prime minister, minister of finance), allowing it to manage monetary policy. Ministers, however, enjoy informational advantages over backbench legislators and coalition partners: the cabinet often has a higher level of policy expertise or can obfuscate its policy intentions. These information asymmetries allow cabinet ministers to manipulate monetary policy for their own benefit, even if it means hurting the interests of party legislators or coalition partners. As a result, party legislators and coalition partners may be quick to withdraw their support from the cabinet over a monetary policy dispute.

Monetary commitments, however, supply information about the cabinet's policy behavior that can reassure party legislators and coalitions partners. A fixed exchange rate, for example, is a "transparent" policy rule--that is, it can be observed at any time and is not subject to the long lags inherent in obtaining inflation and money supply data from the government. ${ }^{19}$ It provides a clear standard to monitor and evaluate the macroeconomic policy choices made by the party holding the finance portfolio. Deviation from that standard sends a signal about the policy choices of the finance minister.

${ }^{19}$ Broz 2002; Aghevli et al. 1991; Bernhard 1998a. 
An independent central bank can also act as a watch-dog over the cabinet's policy actions, sounding alarms in the event of opportunistic policy manipulation. ${ }^{20}$ Because it is not under the direct control of the cabinet, an independent central bank can draw attention to situations where cabinet ministers pressure the central bank-either directly or indirectly - to manipulate policy in ways that deviate from policy objectives.

Moreover, these monetary commitments help policymakers justify difficult policy actions and defend certain outcomes. Party leaders may use monetary commitments to persuade backbench legislators, other parties, and the public that certain policy actions are necessary. With a fixed exchange rate, cabinet ministers may be able to rationalize painful policy measures in the name of defending the exchange rate. The fixed exchange rate allows politicians to frame sensitive policy choices in a manner that is more politically palatable. As one central banker in Europe noted, "It is always easier to sell the decision to defend the exchange rate than to raise interest rates. Unions understand the importance of the exchange rate." ${ }^{21}$ An independent central bank can also provide credible verification that cabinet ministers had attempted to achieve certain outcomes, even if those policy choices unintentionally had consequences unacceptable to their legislative and coalition supporters. In both cases, party legislators and coalition partners, therefore, will be less likely to withdraw their support from the government in the face of negative outcomes. As a result, parties remain in office longer, even if party politicians have different incentives over monetary policy.

${ }^{20}$ Bernhard 2002; Bernhard 1998b.

${ }^{21}$ Personal Interview, Spring 1993. 
Finally, monetary commitments can help parties manage intra-party and intra-coalition conflict by providing a basis for policy agreement and bargaining. A fixed exchange rate, for instance, may provide a focal point for parties with diverse interests over economic policy, particularly in an open economy. ${ }^{22}$ Politicians may simply agree to fix the exchange rate as a way to settle otherwise intractable policy conflicts. Or politicians may agree to delegate policy formation to an independent central bank with clear policy goals, such as price stability. These commitments, therefore, take monetary policy "off the table," removing a potential source of conflict and allowing parties to focus on issues that unite them. ${ }^{23}$

Monetary commitments, therefore, can help political parties manage diverse coalitions. ${ }^{24}$ These commitments can also help restore policy effectiveness and improve economic

${ }^{22}$ Bernhard and Leblang 1999.

${ }^{23}$ Bernhard (2002) suggests that the independence of the German Bundesbank helped the Social Democratic party and the liberal Free Democratic party form a coalition in the 1970s, despite their differences on economic policy. The Bundesbank's ability to criticize the Social Democratic-led government would alert the Free Democrats to any attempts to manipulate monetary policy away from the coalition agreement. Similarly, strong monetary commitments in the Netherlands (a relatively independent central bank, a stable fixed exchange rate) may have facilitated an unlikely coalition between the Labor party (PvdA) and the Liberal party (VVD) in the 1990 s by removing monetary policy as a potential source of conflict.

${ }^{24}$ Monetary commitments also have distributive consequences. Recent literature on the real economic effects of monetary policy begins to identify the distributive consequences-the "winners" and "losers"--of different monetary arrangements (e.g., Hall and Franzese 1998; Franzese 1999; Iversen 1998; Soskice and Iversen 1998). Parties can use these commitments to 
performance. A fixed exchange rate helps stabilize the external trading environment by decreasing uncertainty surrounding the exchange rate and by reducing transactions costs across countries. In addition, a fixed rate can provide a nominal anchor for macroeconomic policy.

A more independent central bank also enhances monetary policy effectiveness. An independent central bank signals to economic agents that monetary policy will be insulated from excessive partisan and electoral manipulation. ${ }^{25}$ Consequently, economic agents will adjust their behavior more quickly, improving policy efficacy. ${ }^{26}$ Improved performance, in turn, can contribute to more cabinet stability.

Monetary commitments, therefore, can help politicians manage intra-party and intra-coalition conflicts over monetary policy, helping these parties to remain in office. At the same time, however, a fixed exchange rate or an independent central bank does entail some political costs: the cabinet loses the ability to manipulate policy for short-term electoral or partisan gain. ${ }^{27}$ But

benefit certain sectors, particularly inflation-averse sectors, while relying on other policies (e.g., fiscal policy, welfare policy) to compensate the policy "losers." Monetary commitments, therefore, may be able to help parties assemble and maintain diverse electoral coalitions.

25 For example, Alesina 1989; Cukierman 1992; Grilli, Maciandaro, and Tabellini 1991; Lohmann 1998.

${ }^{26}$ Empirical evidence does not bear out this theoretical expectation. Several researchers have investigated how central bank independence affects the "costs" of disinflation in terms of lost output and increased unemployment. These studies show that the costs of disinflation are actually higher under an independent central bank (Posen 1998; Walsh 1995a).

${ }^{27}$ Further, a fixed exchange rate implies a loss of domestic monetary policy autonomy (Mundell 
where intra-party conflicts threaten the party's ability to win and stay in office, the political benefits of a monetary commitment outweigh these costs. Therefore, we expect that monetary commitments enhance cabinet durability, especially under conditions of economic openness.

\section{Economic Openness, Monetary Institutions, and Cabinet Durability}

In order to determine the political value of monetary commitments, this section tests the relationship between economic internationalization, monetary commitments, and cabinet durability. We expect that monetary commitments will be associated with higher levels of cabinet durability, particularly for open economies.

\section{Independent Variables}

\section{Economic Openness}

We measure economic openness along two dimensions. The first dimension reflects barriers to the movement of assets across borders. Increased internationalization implies fewer restrictions on the movement of capital and traded goods across borders, including no capital controls, full convertability of currencies, no restrictions on the current account, and no tariff or non-tariff barriers to trade. As a proxy for this variable, we use a measure of restrictions on international transactions compiled by Quinn (1997). This variable measures both capital account and current account openness. It ranges from 7 (high restrictions) to 14 (no restrictions). ${ }^{28}$

1961). Without the ability to use monetary policy to counter localized economic shocks, countries may suffer unnecessary welfare losses in output or unemployment.

${ }^{28}$ In alternative specifications, we used 1) a dummy variable for capital controls from Leblang (1997) and 2) the measure of capital account openness developed by Quinn (1997). The results from all three measures were qualitatively similar, although at varying levels of statistical significance. 
The second dimension reflects the degree of exposure to the international economy. We measure this by the sum of imports and exports as a proportion of gross domestic product. This trade openness variable ranges from 18 percent to 148 percent of G.D.P. We expect both the restrictions on international transactions and trade openness to have a negative effect on cabinet durability.

\section{Exchange Rate Commitments}

We include two variables to account for exchange rate commitments. The first dummy variable, Fixed Exchange Rate, is coded one when a country had a pegged exchange rate or participated in the European Monetary System after $1987^{29}$ at the date of the cabinet's installation. We included another dummy variable, Post-Maastricht, from January 1993 until the end of the sample for governments that participated in the European Monetary system during that

29 In preliminary analyses, we divided participation in the European Monetary system into three periods: 1979-1986; 1987-1992; 1993-1998 (Gros and Thygesen 1998). During the first period, the system underwent a series of realignments, ending in January 1987. Between 1987 and 1992, no devaluations occurred and the E.M.S. "hardened" into a quasi-fixed exchange rate regime until the September 1992 currency crisis. The third period, 1993-1998, represents the run-up to E.M.U, which began in January 1999. The effects of these three periods on cabinet durability differed dramatically. In the first period, participation in the E.M.S. did not have any effect on cabinet durability. Consequently, we coded participation in the E.M.S. from 1979-1986 as a floating exchange rate. In the subsequent two periods, participation had a statistically significant effect on cabinet durability. Participation in the E.M.S. after 1987, therefore, is coded as having a fixed exchange rate. 
time. $^{30}$ Data are from Cobham (1994); Gros and Thygesen (1998), and the I.M.F.'s "Exchange Arrangements and Exchange Restrictions Annual Report" (various years). We interacted the exchange rate variables with the economic openness variables.

Central Bank Independence

We include a measure of central bank independence from Cukierman, Webb, and Neyapti (1992). We update this measure to reflect central bank reform in Belgium, France, Italy, and New Zealand during the sample period. ${ }^{31}$ We also interacted central bank independence with the trade and restrictions on international transactions variables as well as the fixed exchange rate and post-Maastricht variables.

\section{Coalition and Party System Attributes}

According to the political science literature, cabinet durability is a function of coalition attributes and party system attributes. ${ }^{32}$ Coalition attributes reflect the majority status of the government and the number of parties in the government. We distinguish three government

${ }^{30}$ This includes Denmark and, after 1995, Sweden—countries that participated in the E.M.S. until 1999, but then opted out of the single currency. For Austria, Finland, and Sweden, countries that joined the E.U. in 1995-96, we code them as participating in the E.M.S. beginning in 1996.

${ }^{31}$ The rankings of central bank independence for reformed central banks are based on Tavelli, Tullio, and Spinelli (1998), who used the Grilli, Masciandaro and Tabellini (1991) criteria. We used the same criteria to compute the value for the reformed New Zealand central bank. We then used these updated rankings to impute the new values in the Cukierman, Webb, and Neyapti (1992) index.

32 Alt and King 1994; King, Alt, Burns, and Laver 1990; Laver and Schofield 1990; Warwick 1994. 
types: single-party majority governments; minimum-winning coalitions; and minority \& oversize coalitions governments. $^{33}$ We interacted these dummy variables with the economic internationalization and monetary commitment variables.

The literature indicates that single party majority governments tend to be most durable, minimum winning coalitions slightly less durable, and oversize and minority governments least durable. ${ }^{34}$ Since single-party majority governments already tend to be durable, we expect the monetary commitment variables will have little effect on their durability. Instead, we expect fixed exchange rates and central bank independence to have a larger impact on the cabinet durability of coalition governments. In each of the models, single-party majority governments are the omitted category.

Party system attributes include fragmentation of the political system and political polarization. Political scientists argue that the more fragmented and polarized the political system, the shorter the expected cabinet duration. We include a variable for party system fractionalization, which measures the number of effective political parties in the system. ${ }^{35}$ This variable should have a negative effect on cabinet durability. Polarization is measured by the

33 We originally identified four government types: single-party majority, minimum-winning coalitions, oversize coalitions, and minority governments. Initial statistical analyses, however, indicated that the minority and oversize coalitions tend to have similar cabinet durabilities. As a result, we collapse them into one type.

${ }^{34}$ For example, Lijphart 1999; Laver and Schofield 1990.

35 Rae 1971. 
electoral support for extremist parties. $^{36}$ More support for extremist parties also implies shortened duration.

We also include a dummy variable to capture exogenous electoral timing. In systems with exogenous electoral timing, cabinets are like to last longer since party leaders know that they must work with the existing distribution of legislative seats. As a result, they may be less likely to withdraw their support from the government coalition.

Summary statistics for all variables are contained in table 1.

\section{Sample, Dependent Variable, and Methodology}

\section{Sample}

The sample includes 193 cabinets from sixteen countries: Australia, Austria, Belgium, Britain, Canada, Denmark, Finland, France, Germany, Ireland, Italy, Japan, Netherlands, New Zealand, Norway, and Sweden. ${ }^{37}$ The sample extends from roughly 1972 to 1998 . For each country, the sample begins with the first cabinet installed after 1972 and ends with the last cabinet that dissolved by January 1, 1999. There are no censored data in the sample.

\footnotetext{
${ }^{36}$ According to Powell (1982), extremist parties exhibit one of the following characteristics: 1) A well-developed nondemocratic ideology; 2) A proposal to break-up or fundamentally alter the boundaries of the nation; or 3) Diffuse protest, alienation, and distrust of the existing political system. We follow Powell's classifications with the exception of including France's National Front.
}

${ }^{37}$ Switzerland was excluded due to the permanent oversize status of their executive council. Other countries were excluded due to limitations in the availability of data. 
The number of cabinets varies substantially across the countries in the sample. Austria, Britain, Canada, the Netherlands, and Germany had the fewest governments (8 each) while Italy and Japan had the most governments (24 and 20, respectively).

\section{Dependent Variable}

For the dependent variable, we could simply use the number of months that a cabinet is in office. Constructing the dependent variable in this manner, however, leads to complications that could bias the results. First, countries have different constitutionally-mandated electoral terms-three, four, or five years-that define the maximum time a government can hold office. If the dependent variable is simply the number of months in office, we would not be able to discern whether a cabinet completed its maximum term or if the cabinet ended prematurely. Second, measuring the dependent variable as number of months in office obscures the durability of cabinets that do not form at the beginning of the electoral term. Consider two hypothetical cabinets in a system with a four-year electoral term. The first cabinet forms immediately after an election and serves two years before collapsing. The second cabinet forms with only two years left before a mandated election and then serves out its maximum term. If the dependent variable were measured in months in office, both would be counted as two years, even though the latter served its maximum term.

To overcome these issues, we construct a dependent variable that measures cabinet duration as the proportion of the maximum term available when the cabinet takes office (measured in days). That is, a cabinet that lasts three years (1095 days) out of a possible four (1460 days) would score a 0.75 . A cabinet that formed only 365 days before constitutionally mandated elections and survived for that year is coded $1 .^{38}$

38 Because the dependent variable is truncated, it is possible that the residuals will not be normally distributed. We performed a Jarque-Bera test for the normality of the residuals. For model III, the main model of interest, the chi-squared statistic of 0.0457 (p-value of 0.9974) did 
We included a control variable, Time to Election, measuring the maximum number of days that a government could potentially be in office. ${ }^{39}$ The longer the potential time a government can be in office increases the possibility that a government will collapse during its term. Consequently, we expect this variable to have a negative coefficient.

\section{Methodology}

We employ two estimation methods. The literature on cabinet formation as well as clear cross-national differences in cabinet duration suggests that country-specific factors-for example, similar political institutions or practices-will affect all cabinets in that country. As a consequence, there may be unequal variation in cabinet durability across countries. For example, cabinet duration in Italy may differ a great deal, while the length of cabinets in Germany is relatively similar. To deal with this issue, we perform OLS regression with robust (Huber-White) standard errors. This method assumes that observations are independent across countries, but not necessarily independent within countries.

In the discussion, we use expected values from the model to evaluate different institutional reforms in the industrial democracies. The procedure to calculate those expected values, however, does not support OLS regression with robust standard errors. As a consequence, we

not allow us to reject the null hypothesis of normality. We also re-estimated the models in table 2 using a variant of robust regression (Welsch 1980; Western 1995). This technique produces parameter estimates and standard errors that are "robust" to departures from normality. Results from the robust regression estimation did not substantively alter the estimated parameters and only attenuated the standard errors in a few cases.

${ }^{39}$ In alternative specifications, we ran the analysis without this control variable. The results were similar. 
rely on simple ordinary least squares regression for those calculations. OLS is a more conservative technique- the standard errors will be larger than the robust standard errors. ${ }^{40}$

\section{$\underline{\text { Results }}$}

Table 2 contains the results. Column entries are parameter estimates and standard errors are in parenthesis. Models I, II, and III are estimated using OLS with robust standard errors. Model IV is estimated using OLS.

Model I provides a baseline model of cabinet duration, based solely on attributes of the governing coalition and the party system. The model as a whole is statistically different from zero. Polarization and exogenous electoral timing are statistically significant and in the predicted direction. Consistent with the literature, the parameter estimate for polarization indicates that more heterogeneous party systems produce cabinets that survive for shorter times. On the other hand, cabinets in systems with exogenous electoral timing last longer. ${ }^{41}$ The other variables are not statistically different from zero, although each is in the predicted direction.

\footnotetext{
${ }^{40}$ We ran the model using two other methods: OLS Regression with Panel-Corrected Standard Errors and Panel Specific AR(1) and a variant of robust regression. The panel-corrected standard errors and panel specific $\mathrm{AR}(1)$ are designed to correct for potential serial correlation in the residuals (Beck and Katz 1996; 1995). Robust regression helps minimize the influence of outliers or overly-influential cases (Welsch 1980; Western 1995). The results from both procedures were similar to the results obtained OLS with robust standard errors (Results available on request).
}

\footnotetext{
${ }^{41}$ This result may be an artifact of how we measure the dependent variable. With exogenous electoral timing, the last cabinet of an electoral term must serve its maximum term, potentially increasing the number of cabinets that have a value on the dependent variable equal to 1 .
} 
Model II includes variables for central bank independence, fixed exchange rates, and participation in the post-Maastricht E.M.S. The polarization and exogenous electoral timing variables remain significant and in the predicted direction. The minority/oversize coalition variable becomes statistically significant. As the literature indicates, these types of governments do not last as long as single-party majority governments.

The central bank variable is, as predicted, positive and significant. Systems with independent central banks have higher levels of cabinet durability. For a hypothetical government beginning a potential four-year term in office, increasing the level of central bank independence from 0.2 (about one-standard deviation below the mean) to 0.5 (about one standard deviation above the mean) increases expected durability by about 88 days-almost three months.

The fixed exchange rate variable is also positive and attains a marginal level of statistical significance $(\mathrm{p}<0.07)$. Countries with a fixed exchange rate appear to have higher levels of cabinet durability. For that same hypothetical government beginning a four-year term in office, the expected cabinet durability is 146 days more with a fixed exchange rate than without—an increase of nearly 5 months. The post-Maastricht variable is also positive, although not statistically significant.

The results clearly indicate that monetary commitments can increase cabinet durability. But Model II does not tell us how these monetary commitments interact with a country's economic and political attributes to affect cabinet durability. Model III adds variables capturing economic internationalization. Given the collinearity of the interaction terms, few of the terms are individually statistically distinguishable from zero. As a result, we report a series of Wald tests for each set of variables. These results indicate that we can reject the null hypothesis that none of the sets of variables, except minority/oversize coalitions, has any statistically significant influence on the cabinet durability at the 0.05 level. $^{42}$

\footnotetext{
${ }^{42}$ As a robustness check, we re-ran the analysis deleting one country at a time. The sets of
} 
How do these results conform with our expectations about the influence of economic openness and monetary commitments on cabinet durability? We first note that the overall effects of both trade and restrictions on international transactions are negative, holding all other variables at their means and assuming a floating exchange rate. Increasing trade by one standard deviation from its sample mean leads to a reduction in cabinet durability by 0.03 ; however, this effect is not statistically significant. On the other hand, reducing the number of restrictions on international transactions from the sample mean of 11 by one standard deviation decreases cabinet durability by 0.14 , a statistically significant effect. In other words, given an increase in the restrictions variable from 11 to 13 , the expected duration of a hypothetical cabinet facing a four-year term would drop by about 200 days.

We present the results for monetary commitments two ways. First, we graph the relationship between central bank independence and cabinet durability for different government types (Figure 1). Holding all other variables constant, ${ }^{43}$ we generated expected values of cabinet durability using the sample range of central bank independence. ${ }^{44}$ The X-axis represents the range of variation for the central bank independence variable. The $\mathrm{Y}$-axis represents the expected values of cabinet duration.

variables remained significant throughout this procedure.

${ }^{43}$ The restrictions and trade variables were held at their means. The exchange rate and postMaastricht variables were held at zero. In other words, these results are for floating exchange rate regimes.

${ }^{44}$ For ease of presentation, we do not report confidence intervals around the expected cabinet durability. 
The line marked "Effect of CBI for Single Party Majority Government" illustrates how central bank independence affects cabinet durability for single party majority governments. The slope of this line is virtually horizontal. That is, central bank independence does not have much, if any, effect on cabinet durability for single party majority governments. This is consistent with expectations—single party majority governments should be relatively stable regardless of the institutional commitments. For coalition governments, however, central bank independence has a positive effect on cabinet durability, particularly for minimum winning coalitions. The line marked "Effect of CBI for Minimum Winning Coalitions" is sharply positive, while the line "Effect of CBI for Minority Governments and Oversize Coalitions" is positive as well. For minimum winning coalitions, in particular, central bank independence has a beneficial effect on cabinet durability. At high levels of central bank independence, minimum winning coalitions outlast even single party majority governments!

How does an exchange rate commitment interact with central bank independence to affect cabinet durability? Holding all other variables at their means, we examined the relationship between central bank independence and cabinet durability in systems with a fixed exchange rate (Figure 2). For single party majority governments with an exchange rate commitment, central bank independence has a slightly negative relationship with cabinet durability. Comparing Figures 1 and 2 shows that a fixed exchange rate does appear to provide slightly higher cabinet durability for single party majority governments, particularly at low levels of central bank independence, but this effect is not statistically significant.

For minimum winning coalitions, central bank independence still has a sharp, positive relationship with cabinet durability, even under a fixed exchange rate. A comparison of Figures 1 and 2 indicates that, at low levels of central bank independence, a fixed exchange rate appears to depress expected cabinet durability while at high levels of central bank independence, a fixed exchange rate appears to increase expected cabinet durability. In neither case, however, is the 
difference statistically significant. An exchange rate commitment, therefore, does not affect the cabinet durability of minimum winning coalitions.

Finally, with an exchange rate commitment, central bank independence has a slightly negative effect on cabinet durability for minority and oversize coalition governments (Figure 2). At low levels of central bank independence, a fixed exchange rate provides a statistically significant increase in expected cabinet durability. At high levels of central bank independence, an exchange rate commitment reduces cabinet durability, although the difference between a fixed and floating exchange rate is not statistically significant except for very high levels of central bank independence. With a dependent central bank, minority and oversize coalition governments, therefore, benefit from a fixed exchange rate. That fixed exchange rate may provide a focal point for parties, helping to foster agreement about monetary policy.

But how do monetary commitments and economic conditions interact to affect cabinet durability? The previous figures held economic conditions constant at their sample means. But economic conditions vary substantially across countries and over time. These conditions are likely to affect the relationship between monetary commitments and cabinet durability. To examine these interactions, we compared expected cabinet durabilities based on different configurations of monetary commitments and economic conditions. For each government type we determined expected cabinet durability for different levels of openness, varying both restrictions on international transactions (from 10, high restrictions, to 14, few restrictions) and trade openness (from $20 \%$ of GDP to $100 \%$ of GDP). For each combination of economic openness, we then calculated expected cabinet durability for four different institutional configurations: a dependent central bank $(\mathrm{CBI}=0.20)$ and floating exchange rate; a dependent central bank and fixed exchange rate; an independent central bank $(\mathrm{CBI}=0.52)$ and a floating exchange rate; an independent central bank and a fixed exchange rate. ${ }^{45}$ We then compared the

\footnotetext{
${ }^{45}$ Expected values and 95\% confidence intervals were calculated using procedures suggested by
} 
expected values to determine which configuration of monetary institutions provided the highest cabinet durability for that level of openness. ${ }^{46}$

For single-party majority governments, cabinet durability is unaffected by the configuration of monetary institutions at moderate to low levels of economic openness. Each institutional combination provides a statistically similar expected cabinet durability. This result squares with our expectation that single party majority cabinets will be uninfluenced by monetary commitments. At higher levels of openness (trade at 80 or above), a fixed exchange rate provides the highest levels of cabinet durability. With an exposed economy, the economic benefits of a fixed exchange rate (e.g., a more stable trading environment) may outweigh the political costs of losing the ability to manipulate monetary policy for electoral or partisan advantage. Interestingly, at high levels of openness, an independent central bank provides the lowest levels of expected cabinet durability.

The pattern is substantially different for minimum winning coalitions. For all except the very highest levels of economic openness, an independent central bank provides the highest levels of cabinet durability. For the most part, the exchange rate regime does not matter for cabinet durability. Only at very high levels of trade does the effect of the fixed exchange rate appear to dominate the effect of an independent central bank.

Finally, for minority and oversize coalition governments at low levels of openness, an independent central bank delivers the highest levels of cabinet durability. But at even modest levels of economic openness, a dependent central bank and a fixed exchange rate produce the highest cabinet durability. A fixed exchange rate provides a focal point for parties in these

King, Tomz, and Wittenberg (2000).

${ }^{46}$ Results are available on request. 
governments. That focal point becomes more important as more constituents are exposed to the international economy.

Monetary commitments can improve cabinet durability, but the effect depends on both the level of economic openness and political circumstances. The tenure of single-party majority governments is, for the most past, unaffected by monetary commitments. Coalition governments, on the other hand, can benefit from fixed and exchange rates and central bank independence. These differences can help explain patterns of monetary and institutional reform in the industrial democracies.

\section{Monetary and Institutional Reform in the Industrial Democracies}

Over the past 30 years, the economies of the industrial democracies have become more open and integrated. ${ }^{47}$ Increased levels of economic internationalization have altered the political environment. Changes in both the policy preferences of constituents and the government's policy efficacy have not only challenged parties to maintain their traditional constituents, but also provided them with opportunities to expand their electoral coalitions. Therefore, many political parties have modified their electoral strategies and policy priorities. ${ }^{48}$ Part of this strategic repositioning includes the support of institutional reforms (Table 3). Institutional reform can provide outlets for the representation of new interests, demonstrate policy commitment to affected constituents, or enhance policy effectiveness. Institutional reforms, therefore, can

47 For the purposes of this paper, we assume that changes in the level and degree of economic openness are exogenous. While we recognize that governments can, to a certain degree, manipulate the level of economic openness, much of the increased interactions across borders reflect technological advances in communication and transportation.

48 Boix 1998; Kitschelt 1994; Garrett 1998. 
potentially help parties balance the interests of party politicians with divergent policy incentives, re-establish an electoral coalition, and preserve the party's position in office.

Political parties will pursue institutional reforms when it is in their interest to do so. Parties are, of course, interested in attaining and retaining office. If institutional reform can help the government survive longer, politicians are likely to pursue those reforms. If reforms will shorten the government's tenure in office, politicians will not implement those institutional changes.

Comparing the expected cabinet durabilities of different configurations of monetary commitments allows us to evaluate the political benefit or cost of different institutional options (in terms of cabinet durability), and predict which reforms are more or less likely. The statistical results show that the durability of single-party majority governments is generally unaffected by monetary commitments. Assuming that the implementation of reform is costly, this implies that single-party majority governments will not often pursue monetary reform. Coalition governments, on the other hand, do benefit from monetary commitments. In particular, the duration of minimum-winning coalitions benefits from central bank independence, suggesting that those government types will pursue a more independent central bank. Minority and oversize coalition governments, on the other hand, benefit from central bank independence only at low levels of economic openness. At moderate levels of openness, a fixed exchange rate provides the highest levels of cabinet durability. As a result, we expect countries with minority and oversize coalition governments to make exchange rate commitments.

\section{Institutional Change and Cabinet Durability}

In order to examine these predictions, we use the results of model III to generate expected values of cabinet durability based on counterfactual configurations of monetary institutions for each country at four different time periods: 1979-1981, 1984-1986, 1989-1991, 1994-1996. For each time period, we used the actual values of trade exposure and restrictions on international transactions to capture changing levels of economic openness. We then compared the expected 
cabinet durability from the actual configuration of institutions with the expected cabinet durability from other potential institutional choices.

In these simulations, we assumed a constant government type for each country across all four periods unless there was a major electoral reform. We calculated the percentage of time that each of the three government types—single party majority, minimum winning coalition, and minority/oversize coalitions_-served in office during the sample period. We used those proportions as each country's assumed government type. ${ }^{49}$ If a country underwent a major electoral reform that changed the predominant government type, we changed the assumed government type in the subsequent simulation period. New Zealand, for instance, reformed their electoral system in the early 1990 s, moving from a majoritarian electoral system to a mixed majoritarian-proportional representation system. Prior to the reform, New Zealand had usually experienced single party majority governments. Since the reform, minimum winning coalitions have become the norm. The assumed values for New Zealand's government type in 1994-1996 reflect that change.

We argue that politicians are not going to pursue any reforms that significantly hurt their ability to stay in office. In other words, we expect the predicted cabinet durability associated with actual institutional reforms to be statistically indistinguishable or higher than the expected cabinet durability associated with status quo institutions. To evaluate this argument, table 4 compares

\footnotetext{
${ }^{49}$ In about half the countries, one government type held office for over $95 \%$ of the period. For example, Germany experienced only minimum winning coalitions. In those countries, we assumed that particular government type for all the simulations. For the other countries, we used the proportion of different government types for the simulations. In Belgium, for example, minimum-winning coalitions were in place for about $65 \%$ of the period, while minority and oversize coalition governments comprised the other $35 \%$.
} 
expected cabinet durability in 1994-1996 assuming the institutions of 1979-1981 were in place with the expected cabinet durability in 1994-1996 with the actual (reformed) institutions in place. (Recall that in 1979-1981, we coded participation in the E.M.S. as equivalent to a floating exchange rate). Of the 16 countries in the sample, 13 had reformed the exchange rate commitment, the central bank, or the electoral system (i.e., predominant government type). ${ }^{50}$ Of those 13 countries, six had a statistically significant higher expected cabinet durability under the reformed institutions than they would have had with the 1979-1981 institutions in place. Only one country, New Zealand, would have enjoyed significantly higher cabinet durability under the old set of institutions. $^{51}$

${ }^{50}$ Both Britain and Norway altered their exchange rate institutions during the time period, but by the mid-1990s, each had returned to an exchange rate arrangement similar to the one in place in 1979-1981.

${ }^{51}$ In 1979-1981, New Zealand had a single-party majority government, a dependent central bank, and a fixed (but relatively soft) exchange rate commitment. Between June 1979 and June 1982 New Zealand's currency crawled with respect to a trade-weighted basket. However, the rate of crawl was not announced but was adjusted to inflation differentials. After mid-1982, New Zealand returned to a more fixed exchange rate arrangement. In 1985, New Zealand dropped its fixed exchange rate, a move that had no statistically discernable effect on cabinet durability at that time. In 1989-1990, New Zealand adopted an independent central bank and then, a few years later, a proportional representation system. The combination of those reforms produced an expected cabinet durability in 1994-1996 that was equivalent to the expected cabinet durability of a single party majority government, a dependent central bank, and a floating exchange rate $(0.73$ v. 0.71). 
A second way to evaluate the argument is to examine the impact of individual reforms. Of the 38 individual reforms in table 3 , eleven had a statistically positive impact on cabinet durability - about a third of the reforms. In contrast, only three had a statistically significant negative effect on expected cabinet durability: Italy's exit from the E.M.S. in 1992, Norway's abandonment of a fixed exchange rate in 1992, and Belgium's decision to grant their central bank more independence in 1993. These incidents constitute about 8 per cent of observed reforms. The other 24 reforms have no statistically discernable effect on cabinet durability.

\section{Exchange Rate Commitments and Coalition Governments}

The statistical results indicate that exchange rate commitments provide higher levels of cabinet durability for minority and coalition governments, particularly in open economies. These results square with the empirical association between the adoption of exchange rate commitments and small, open, proportional representation systems in western Europe. ${ }^{52}$ Austria, Sweden, Norway, and Finland pegged their exchange rates throughout much of the sample period. Each would have had significantly lower cabinet durability if it had moved to a floating exchange rate.

Participation in the E.M.S. after 1987 also significantly increased cabinet durability for Belgium, Ireland, and the Netherlands. In Belgium, for instance, expected cabinet durability increased by 0.30 or over 430 days for a hypothetical government facing a four-year term. Of the other E.M.S. members, all experienced an increase in expected cabinet durability, although none was statistically significant. Participation in the E.M.S. after 1993 significantly increased expected cabinet durability for Denmark and the Netherlands-even beyond participation in the E.M.S. In the Netherlands, expected cabinet durability increased by 0.28 or just over 400 days for a four-tear term. For other member states within the E.M.S., the post-Maastricht period had a positive but insignificant effect on cabinet durability.

\footnotetext{
52 Bernhard and Leblang 1999.
} 
Interestingly, prior to the 1990s, the post-Maastricht variable produces a statistically significant decline in expected cabinet durability for all but two member states. It is not until the completion of the internal market and the removal of all cross-border restrictions that such an extraordinary exchange rate commitment enhances cabinet durability. A similar pattern emerges for countries seeking membership in the E.U. during the mid-1990s-Austria, Finland, Sweden, and Norway. Prior to the mid-1990s, joining the E.U. would have resulted in a significantly lower expected cabinet durability for each of these applicant countries. In the mid-1990s, however, participating in the post-Maastricht E.M.S. did not hurt-and, in some cases, improved—expected cabinet durability.

The results also indicate that the Maastricht Treaty requirement for each member state to grant its central bank independence as a precondition to participation in the final stage of E.M.U. was relatively costless to implement in terms of cabinet durability. For the eight member states in the sample which participated in the E.M.S. at some point during the 1990s and had relatively dependent central banks (i.e., $\mathrm{CBI}<0.50$ ), the effect of granting the central bank more independence (i.e., moving CBI to 0.52 , about one standard deviation above the mean) had no statistically significant impact on cabinet durability. In only Belgium did central bank independence have a negative and statistically significant effect on expected cabinet durability.

The actual data on cabinet durability bear out these predictions. For the core E.M.S. states in the sample (Belgium, Denmark, France, Germany, Ireland, and the Netherlands), ${ }^{53}$ actual cabinet durability improved significantly after 1993. Prior to 1993 , the mean cabinet durability for these countries was 0.51. After 1993, mean cabinet durability increased to 0.77 (two-tailed t-test,

53 Italy left the E.M.S. in 1992 and rejoined in 1996. Even if Italy is included in this group, cabinet durability improved after 1993, although the difference is only marginally significant $(\mathrm{p}<0.07)$. 
$\mathrm{p}<0.02)$. This increase is even more impressive in the face of a European-wide economic slump during the period, which might have been expected to shorten cabinet durability. Indeed, for sample countries outside the E.M.S., average cabinet durability declined after 1993 (0.67 prior to 1993; 0.58 after), although this decline was not statistically significant. The commitment to the post-Maastricht E.M.S. appears to have helped those member state governments weather the economic downturn in the 1990s.

These results suggest a political rationale for E.M.U.: helping member state governments cope with the political consequences of economic internationalization. A commitment to the single currency removes a potentially divisive policy issue from the domestic political agenda. Moreover, the Maastricht Treaty requirements helped politicians pursue fiscal retrenchment, providing both incentives for and justification of fiscal discipline. ${ }^{54}$ The single currency, therefore, can help parties avoid intra-party and intra-coalition conflicts over economic policy, preserving their positions in office and allowing them to re-build their social coalitions around other issues areas.

\section{Some Speculation: The Coincidence of Central Bank Reform and Electoral Reform}

The results may also shed some light on the coincidence of monetary and electoral reform. While single-party majority governments tend to be the most stable cabinets, the statistical results indicate that monetary commitments may, under certain circumstances, extend the cabinet durability of minimum-winning coalition governments beyond of a single-party majority cabinet. Assuming that a certain set of monetary institutions is in place, therefore, parties may be able to pursue with electoral reform without the cost of increased cabinet instability. More specifically, if a country has an independent central bank, politicians may change from a majoritarian electoral system that produces single-party majority governments to an electoral system that produces

${ }^{54}$ Hallerberg 1999; Hallerberg and von Hagen 1999; McNamara 2000. 
minimum winning coalitions (e.g., disproportionate proportional representation) without sacrificing cabinet durability. The beneficial combination of an independent central bank and a minimum winning coalition suggests that central bank reform and electoral reform may occur together. ${ }^{55}$ That is, parties might adopt an independent central bank to help preserve cabinet durability at the same time they are considering the adoption of an electoral system designed to produce minimum-winning coalitions.

Consider, for instance, a major party in a majoritarian electoral system, faced with the political consequences of increased economic openness: diversified constituent demands, decreased policy effectiveness, increased intra-party conflict over policy. These intra-party conflicts may threaten to keep the party in opposition by making it increasingly difficult for the party to put forward a unified electoral appeal and, when if office, to maintain party discipline. Party leaders might decide that the party's political fortunes would improve if they could focus on the party's core supporters and allow dissatisfied constituents and legislators to form their own party. One way to encourage these dissatisfied actors to leave the major party—and still maintain the major party's position in the party system--would be to adopt a more proportional (but not fully proportional) electoral system.

One of the potential costs to a major political party of moving from a majoritarian electoral system to a proportional representation system is the prospect of decreased cabinet durability. If cabinets are likely to be unstable, the party might not have access to the policy and distributive benefits of office for as long a period. ${ }^{56}$ An independent central bank, however, can help the

\footnotetext{
${ }^{55} \mathrm{We}$ are not arguing that central bank reform and electoral reform necessarily go together. Both events are far too contingent on a variety of factors for that to be the case.
}

\footnotetext{
${ }^{56}$ Another cost is that the major party would no longer control all the cabinet portfolios (Laver and Shepsle 1996). But party leaders may judge that controlling most of the portfolios for a
} 
parties in a minimum winning coalition overcome their potential differences on economic policy and, as a result, improve cabinet durability. At the same time, each party in the coalition can appeal to the interests of their constituents. Parties, therefore, may use central bank reform as a way to shield themselves from some of the consequences of electoral reform.

Interestingly, central bank reform and electoral reform has coincided in a number of industrial democracies. In New Zealand, the adoption of an independent central bank occurred just prior to major electoral reform. Before the 1990s, New Zealand had possessed a typical "Westminster" system, with two party competition between the Labour Party and the National Party. ${ }^{57}$ In 1989-1990, the Labour government reformed the central bank, uniquely linking the Bank's policy performance with the central bank governor's tenure. ${ }^{58}$ When the National party won the 1990 election, ${ }^{59}$ it honored a pledge it had made in opposition to hold a referendum on the electoral system. ${ }^{60}$ In 1992 , voters rejected the first-past-the-post electoral system, supporting

longer time superior to controlling all of the portfolios for a shorter time (and, when in opposition, controlling none of the portfolios).

\section{${ }^{57}$ Lijphart 1999.}

58 Walsh 1995a; Dalzeil 1993.

${ }^{59}$ The economic reforms instituted by the Labour government had exacerbated existing divisions within the National Party. Consequently, the new National government had a "somewhat unwieldy caucus of backbenchers with widely differing views on the economy" (Keesing's Archives 1991, 37(11): 38643).

${ }^{60}$ The Economist, 26 September 1992. 
a mixed majoritarian-proportional representation system. Since the implementation of that reform, several new parties have appeared and New Zealand has experienced minimum winning coalitions rather than single party majority governments. The expected cabinet durabilities based on the statistical results indicate that electoral reform without central bank reform would have resulted in a shorter cabinet durability (0.71 vs. 0.59) - a difference of about 120 days for a hypothetical government beginning a three-year term. With central bank reform, however, the electoral reform did not have any meaningful effect on expected cabinet durability ( 0.73 vs. 0.71$)$.

In Britain, the Labour government announced the 1997 reform of the Bank of England amid plans for other institutional changes, including regional devolution and the exploration of electoral reform. The Jenkins Committee proposed an alternative vote system combined with additional member constituencies, a compromise between the traditional first-past-the-post system and proportional representation that would likely produce minimum winning coalitions. In the absence of central bank reform, the proposed electoral reform would shorten expected cabinet durability (0.66 vs. 0.57 ) or about 240 days for a hypothetical government beginning a five-year term. With a more independent Bank of England, however, the electoral reform will have no effect on expected cabinet durability.

In both Italy and Japan as well, central bank reform and electoral reform also occurred closely together. In Italy, just as the central bank received greater policy autonomy from the government in the early 1990s, the political system disintegrated under the weight of corruption scandals, increasing regional disparities, and voter dissatisfaction with Italy's ruling parties, particularly the Christian Democrats. In a series of referenda, Italian voters approved an unusually complicated mixed majoritarian-P.R electoral system. Both reforms were designed, in part, to increase cabinet stability. In Japan, central bank reform (1998) followed shortly after electoral reform in 1993. The electoral reforms have produced a series of coalition governments to replace the L.D.P.'s dominance of the political system. 
The coincidence of central bank reform and electoral reform suggests a similar underlying cause: politicians are seeking to insulate themselves from the political consequences of economic internationalization. Established political parties are using institutional reforms to balance conflicting interests, rebuild social coalitions, and maintain electoral viability. An independent central bank can help protect cabinet durability even as politicians explore alternative electoral arrangements.

\section{Conclusion}

In one sense, the findings in this paper are not particularly controversial. As with much of the recent literature in international political economy, we make a connection between increased economic internationalization and monetary commitments. What is different, however, is the mechanism that links internationalization and those monetary commitments. Much of the literature contends that economic openness-particularly international capital mobility--presents an external constraint on policymakers, forcing them to choose certain types of policies and commitment technologies. Instead, we provide an explicitly political mechanism to link internationalization and monetary commitments: party leaders use monetary commitments to help manage the political consequences of economic internationalization.

Increased openness alters the policy preferences of constituents in the electoral coalitions of the traditional governing parties, creating the potential for policy conflict among constituents and among party politicians. Internationalization also decreases the ability of the government to deliver macroeconomic outcomes. Both these developments are likely to hurt the ability of the traditional parties to maintain their position in office. Under certain circumstances, however, monetary commitments can help parties balance those diverse interests and increase their policy effectiveness. And where politicians benefit from those monetary commitments, they are likely to adopt them.

Our focus on cabinet durability is simply one way to measure the political value of fixed exchange rates and central bank independence. The results indicate that both exchange rate 
commitments and central bank independence can improve cabinet durability, but their effects depend on the level of economic openness and the configuration of domestic political institutions. By placing the incentives and goals of political parties at the center of the analysis, however, we can begin to explain the supply of both exchange rate commitments and central bank independence. 


\section{References}

Aghevli, Bijan B., Mohsin S. Khan, and Peter J. Montiel. 1991. Exchange Rate Policy in

Developing Countries: Some Analytical Issues. Washington, D.C.: International Monetary

Fund.

Alt, James and Gary King. 1994. "Transfers of Governmental Power: The Meaning of Time

Dependence." Comparative Political Studies 27(2):190-210.

Beck, Nathaniel and Jonathan Katz. 1996. "Nuisance vs. Substance: Specifying and Estimating Time-Series-Cross-section models." Political Analysis 6:1-36.

Beck, Nathaniel and Jonathan Katz. 1995. "What to do (and not to do) with Time-Series CrossSection Data." American Political Science Review 89:634-47.

Bernhard, William. 2002. Banking on Reform: Political Parties and Central Bank Independence in the Industrial Democracies. Ann Arbor: University of Michigan Press.

Bernhard, William. 1998a. "Political Accountability in the European Monetary System." Typescript, University of Illinois at Urbana-Champaign.

Bernhard, William. 1998b. “A Political Explanation of Variations in Central Bank Independence.” American Political Science Review 92(2):311-28.

Bernhard, William and David Leblang. 1999. "Democratic Institutions and Exchange Rate Commitments.” International Organization 53(1):71-97. 
Boix, Carles. 1998. Political Parties, Growth, and Equality: Conservative and Social

Democratic Economic Strategies in the World Economy. New York: Cambridge University Press.

Broz, J. Lawrence. 2002. "Political System Transparency and Monetary Commitment Regimes." International Organization.

Clarida, Richard, Jordi Galí, and Mark Gertler. 1999. “The Science of Monetary Policy: A New Keynesian Perspective.” Journal of Economic Literature XXXVII(December):1661-1707.

Clark, William Roberts. 1999. Structuring Strategies: Capital Mobility, Central Bank Independence, and the Political Control of the Economy. Forthcoming, University of Michigan Press.

Clark, William Roberts and Mark Hallerberg. 2000. "Mobile Capital, Domestic Institutions, and Electorally Induced Monetary and Fiscal Policy.” American Political Science Review 94(2):32346.

Cobham, David (ed.). 1994. European Monetary Upheavals. Manchester: Manchester University Press.

Cukierman, Alex. 1992. Central Bank Strategy, Credibility, and Independence: Theory and Evidence. Cambridge: MIT Press.

Cukierman, Alex, Steven B. Webb, and Bilin Neyapti. 1992. "Measuring the Independence of Central Banks and Its Effect on Policy Outcomes.” World Bank Economic Review 6(3): 353-98. 
Dalziel, Paul. 1993. “The Reserve Bank Act: Reflecting Changing Relationships Between State and Economy in the Twentieth Century." In Brian Roper and Chris Rudd (eds.), State and Economy in New Zealand, New York: Oxford University Press.

Franzese, Robert. 2002. Macroeconomic Policies of Developed Democracies. New York: Cambridge University Press.

Franzese, Robert. 1999. "Partially Independent Central Banks, Politically Responsive Governments, and Inflation." American Journal of Political Science 43(3):681-706.

Frieden, Jeffry. 1994. "Making Commitments: France and Italy in the European Monetary System, 1979-1985.” In The Political Economy of European Monetary Unification, edited by Barry Eichengreen and Jeffry Frieden, 25-46. Boulder, CO: Westveiw Press.

Frieden, Jeffry. 1991. "Invested Interests: The Politics of National Economic Policies in a World of Global Finance." International Organization 45: 425-51.

Frieden, Jeffry and Ronald Rogowski. 1996. “The Impact of the International Economy on National Policies: An Analytical Overview.” In Robert Keohane and Helen Milner (eds). Internationalization and Domestic Politics. Cambridge: Cambridge University Press.

Friedman, Milton. 1968. “The Role of Monetary Policy.” American Economic Review 58(1):117. 
Garrett, Geoffrey. 1998. Partisan Politics in the Global Economy. New York: Cambridge University Press.

Goodman, John. 1992. Monetary Sovereignty. Ithaca: Cornell University Press.

Goodman, John and Louis B. Pauly. 1993. "The Obsolescence of Capital Controls? Economic Management in an Age of Global Markets.” World Politics 46: 50-82.

Grilli, Vittorio, Donato Masciandaro, and Guido Tabellini. 1991. "Political and Monetary Institutions and Public Finance Policies in the Industrialized Democracies." Economic Policy 10(October): 342-92.

Gros, Daniel and Neils Thygesen. 1998. European Monetary Integration: From the European Monetary System to European Monetary Union. Second Edition. New York: Longman Press.

Hall, Peter. 1986. Governing the Economy: The Politics of State Intervention in Britain and France. New York: Oxford University Press.

Hall, Peter and Robert Franzese. 1998. "Mixed Signals: Central Bank Independence, Coordinated Wage-Bargaining, and European Monetary Union.” International Organization 52(3):505-35 .

Hallerberg, Mark. 1999. “The Importance of Domestic Political Institutions: Why and How Belgium and Italy Qualified for EMU.” Typescript, University of Pittsburgh. 
Hallerberg, Mark and Jurgen von Hagen. 1998. "Electoral Institutions, Cabinet Negotiations, and Budget Deficits within the European Union.” In James Poterba and Jurgen von Hagen (eds.), Fiscal Institutions and Fiscal Performance. Chicago: University of Chicago Press, 209-32.

Inglehart, Ronald. 1997. Modernization and Postmodernization: Cultural, Economic, and Political Change in 43 Societies. Princeton: Princeton University Press.

Iversen, Torben. 1999. Contested Economic Institutions: The Politics of Macroeceonomics and Wage Bargaining in Advanced Democracies. New York: Cambridge University Press.

Iversen, Torben. 1998. "Wage Bargaining, Central Bank Independence, and the Real Effects of Money." International Organization 52(Summer):469-504.

Iversen, Torben. 1996. "Power, Flexibility, and the Breakdown of Centralized Wage Bargaining: The Cases of Denmark and Sweden in Comparative Perspective." Comparative Politics 28(3):399-436.

Iversen, Torben and Thomas Cusack. 2000. “The Causes of Welfare State Expansion: Deindustrialization or Globalization?" World Politics.

Keohane, Robert and Helen Milner (eds.). 1996. Internationalization and Domestic Politics. New York: Cambridge University Press.

King, Gary, James Alt, Nancy Burns and Michael Laver. 1990. “A Unified Model of Cabinet Dissolution in Parliamentary Democracies." American Journal of Political Science 34(3):846-71. 
King, Gary, Michael Tomz, and Jason Wittenberg. 2000. "Making the Most of Statistical Analyses: Improving Interpretation and Presentation." American Journal of Political Science 44(2):347-61

Kitschelt, Herbert. 1999. "European Social Democracy between Political Economy and Electoral Competition.” In Herbert Kitschelt, Peter Lange, Gary Marks, and John D. Stephens (eds.), Continuity and Change in Contemporary Capitalism, New York: Cambridge University Press, 317-45.

Kitschelt, Herbert. 1994. The Transformation of European Social Democracy. New York: Cambridge University Press.

Laver, Michael and Norman Schofield. 1990. Multiparty Government: The Politics of Coalition in Europe. New York: Oxford University Press.

Laver, Michael and Kenneth Shepsle. 1996. Making and Breaking Governments. Cambridge: Cambridge University Press.

Leblang, David. 1997. “Are Capital Controls Obsolete? Domestic and Systemic Determinants of Capital Controls in the Developed and Developing World." International Studies Quarterly 41(3):435-54.

Lijphart, Arend. 1999. Patterns of Democracy. New Haven: Yale University Press.

Lohmann, Susanne. 1998. "Federalism and Central Bank Independence: The Politics of German Monetary Policy, 1957-1992.” World Politics 50:401-46. 
Loriaux, Michael. 1991. France after Hegemony: International Change and Financial Reform. Ithaca: Cornell University Press.

Lucas, Robert. 1972. "Expectations and the Neutrality of Money." Journal of Economic Theory 4:103-24.

Maxfield, Sylvia. 1997. Gatekeepers of Growth: The International Political Economy of Central Banking in Developing Countries. Princeton: Princeton University Press.

McNamara, Kathleen. 2000. “Globalization, Fiscal Adjustment, and EMU: Race to the Bottom or Room for Maneuver?” Typescript, Princeton University.

Milner, Helen and Robert Keohane. 1996. “Internationalization and Domestic Politics: An Introduction.” In Robert Keohane and Helen Milner (eds). Internationalization and Domestic Politics. New York: Cambridge University Press.

Mundell, Robert. 1961. “A Theory of Optimum Currency Areas.” American Economic Review. 51(4):657-65.

Oatley, Thomas. 1999. "How Constraining is Capital Mobility? The Partisan Hypothesis in an Open Economy." American Journal of Political Science 43(4):1003-27.

Pempel, T. J. 1998. Regime Shift: Comparative Dynamics of the Japanese Political Economy. Ithaca: Cornell University Press. 
Posen, Adam. 1998. “Central Bank Independence and Disinflationary Credibility: A Missing Link?" Oxford Economic Papers 50:335-59.

Powell, G. Bingham. 1982. Contemporary Democracies: Participation, Stability, and Violence. Cambridge: Harvard University Press.

Quinn, Dennis. 1997. “The Correlates of Change in International Financial Regulation.” American Political Science Review 91(3):531-552.

Quinn, Dennis and Carla Inclan. 1997. "The Origins of Financial Openness: A Study of Current and Capital Account Liberalization.” American Journal of Political Science 41(3):771-813.

Rae, Douglas. 1971. The Political Consequences of Electoral Laws, Second Edition. New Haven: Yale University Press.

Rogowski, Ronald. 1989. Commerce and Coalitions: How Trade Affects Domestic Political Alignments. Princeton: Princeton University Press.

Rosenbluth, Frances. 1996. "Internationalization and Electoral Politics in Japan.” In Keohane, Robert and Helen Milner (eds.), Internationalization and Domestic Politics. New York: Cambridge University Press, 137-58.

Roubini, Nouriel and Jeffrey Sachs. 1989a. "Political and Economic Determinants of Budget Deficits in the Industrial Democracies.” European Economic Review 33(2):903-33. 
Roubini, Nouriel and Jeffrey Sachs. 1989b. "Government Spending and Budget Deficits in the Industrial Democracies.” Economic Policy 8:99-132.

Sargent, Thomas J. 1999. The Conquest of American Inflation. Princeton: Princeton University Press.

Shoch, Jim. 2000. Trading Blows: Party Politics and American Trade Policy in the Twentieth Century. Chapel Hill: University of North Carolina Press.

Simmons, Beth. 1999. "The Internationalization of Capital.” In Herbert Kitschelt, Peter Lange, Gary Marks, and John D. Stephens (eds.), Continuity and Change in Contemporary Capitalism, New York: Cambridge University Press, 36-69.

Simmons, Beth. 1994. Who Adjusts? Domestic Sources of Foreign Economic Policy during the Interwar Years, 1924-1939. Princeton: Princeton University Press.

Soskice, David and Torben Iversen. 1998. "Multiple Wage-Bargaining Systems in the Single European Currency Area.” Oxford Review of Economic Policy 14(3):110-24.

Tavelli, Henry, Giuseppe Tullio, and Franco Spinelli. 1998. “The Evolution of European Central Bank Independence: An Updating of the Masciandaro and Spinelli Index.” Scottish Journal of Political Economy 45(3):341-44.

Walsh, Carl. 1995a. “Central Bank Independence and the Short-Run Output-Inflation Trade-off in the European Community." In B. Eichengreen, J. Frieden, and J. von Hagen (eds.), Monetary and Fiscal Policy in an Integrated Europe, New York: Springer, 12-35. 
Walsh, Carl. 1995b. “Is New Zealand's Reserve Bank Act of 1989 an Optimal Central Bank Contract?" Journal of Money, Credit, and Banking 27(4):1179-91.

Warwick, Paul. 1994. Government Survival in Parliamentary Democracies. New York:

Cambridge University Press.

Welsch, Roy. 1980. "Regression Sensitivity Analysis and Bounded-Influence Estimation.” In

Jan Kmenta and James Ramsey (eds.), Evaluation of Econometric Models, New York: Academic Press.

Western, Bruce. 1995. “Concepts and Suggestions for Robust Regression Analysis.” American Journal of Political Science 39(3):786-818. 
Table 1 Descriptive Statistics

\begin{tabular}{lrrrr}
\hline Variable & Mean & $\begin{array}{r}\text { Standard } \\
\text { Deviation }\end{array}$ & Minimum & Maximum \\
\hline Cabinet Durability & 0.57 & 0.31 & 0.008 & 1.15 \\
Time Until Next Election & 1181.18 & 443.06 & 76 & 1822 \\
Minimum Winning Coalition & 0.23 & 0.42 & 0 & 1 \\
Minority/Oversize Coalition & 0.55 & 0.50 & 0 & 1 \\
Fractionalizaiton & 0.69 & 0.10 & 0.41 & 0.88 \\
Polarization & 0.12 & 0.12 & 0 & 0.42 \\
Exogenous Electoral Timing & 0.19 & 0.39 & 0 & 1 \\
Central Bank Independence & 0.33 & 0.14 & 0.17 & 0.69 \\
Fixed Exchange Rate & 0.45 & 0.50 & 0 & 1 \\
Post-Maastricht & 0.06 & 0.23 & 0 & 1 \\
Restrictions on Int'1 Transactions & 11.20 & 1.79 & 7 & 14 \\
Trade & 61.08 & 28.06 & 16.31 & 140.66 \\
\hline
\end{tabular}




\begin{tabular}{|c|c|c|c|c|}
\hline \multicolumn{5}{|c|}{ Table 2 Models of Cabinet Durability } \\
\hline Variables & I & II & III & IV \\
\hline \multirow[t]{2}{*}{ Constant } & $0.92 *$ & $0.78 *$ & -0.11 & -0.11 \\
\hline & $(0.17)$ & $(0.16)$ & $(0.58)$ & $(0.57)$ \\
\hline \multirow[t]{2}{*}{ Time Until Next Election } & -0.00005 & -0.00005 & -0.00005 & -0.00005 \\
\hline & $(0.00005)$ & $(0.00005)$ & $(0.00004)$ & $(0.00005)$ \\
\hline \multirow{2}{*}{ Minimum Winning Coalition } & -0.05 & -0.13 & $-0.33 *$ & -0.33 \\
\hline & $(0.09)$ & $(0.08)$ & $(0.15)$ & $(0.20)$ \\
\hline \multirow{2}{*}{ MWC*CBI } & & & 0.86 & 0.86 \\
\hline & & & $(0.47)$ & $(0.53)$ \\
\hline \multirow[t]{2}{*}{ MWC*Fixed Exchange Rate } & & & -0.54 & -0.54 \\
\hline & & & $(0.32)$ & $(0.36)$ \\
\hline \multirow[t]{2}{*}{ MWC*CBI*Fixed } & & & 0.76 & 0.76 \\
\hline & & & $(0.67)$ & $(0.87)$ \\
\hline \multirow{2}{*}{ MWC $*$ CBI*Post-Maastricht } & & & -0.65 & -0.65 \\
\hline & & & $(0.81)$ & $(2.30)$ \\
\hline \multirow[t]{2}{*}{ Minority/Oversize Coalition } & -0.13 & $-0.16^{*}$ & -0.23 & -0.23 \\
\hline & $(0.08)$ & $(0.07)$ & $(0.16)$ & $(0.17)$ \\
\hline \multirow[t]{2}{*}{ Min/Over*CBI } & & & 0.26 & 0.26 \\
\hline & & & $(0.55)$ & $(0.51)$ \\
\hline \multirow[t]{2}{*}{ Min/Over*Fixed Exchange Rate } & & & -0.01 & -0.01 \\
\hline & & & $(0.28)$ & $(0.31)$ \\
\hline \multirow[t]{2}{*}{ Min/Over*Post-Maastricht } & & & -0.04 & -0.04 \\
\hline & & & $(0.35)$ & $(0.96)$ \\
\hline \multirow{2}{*}{ Min/Over*CBI*Fixed Rate } & & & -0.31 & -0.31 \\
\hline & & & $(0.70)$ & $(0.83)$ \\
\hline \multirow{2}{*}{ Fractionalization } & -0.22 & -0.12 & -0.10 & -0.10 \\
\hline & $(0.27)$ & $(0.22)$ & $(0.31)$ & $(0.33)$ \\
\hline \multirow{2}{*}{ Polarization } & $-0.85 *$ & $-0.79 *$ & $-0.78 *$ & $-0.78 *$ \\
\hline & $(0.15)$ & $(0.16)$ & $(0.19)$ & $(0.24)$ \\
\hline \multirow[t]{2}{*}{ Exogenous Electoral Timing } & $0.21 *$ & $0.16^{*}$ & 0.15 & 0.15 \\
\hline & $(0.05)$ & $(0.05)$ & $(0.08)$ & $(0.08)$ \\
\hline \multirow{2}{*}{ Central Bank Independence } & & $0.20 *$ & $3.72 *$ & $3.72 *$ \\
\hline & & $(0.09)$ & $(1.25)$ & $(1.53)$ \\
\hline \multirow[t]{2}{*}{ Fixed Exchange Rate } & & 0.10 & -0.21 & -0.21 \\
\hline & & $(0.05)$ & $(0.35)$ & $(0.38)$ \\
\hline \multirow{2}{*}{ Post-Maastricht } & & 0.08 & $-4.97 *$ & -4.97 \\
\hline & & $(0.08)$ & $(0.95)$ & $(3.04)$ \\
\hline CBI*Fixed Exchange Rate & & & -0.33 & -0.33 \\
\hline & & & $(0.59)$ & $(0.71)$ \\
\hline CBI*Post-Maastricht & & & -0.14 & -0.14 \\
\hline & & & $(0.59)$ & $(2.22)$ \\
\hline Restrictions on Int'1 Transactions & & & 0.07 & 0.07 \\
\hline & & & $(0.05)$ & $(0.04)$ \\
\hline Restrictions*CBI & & & $-0.24 *$ & $-0.24 *$ \\
\hline & & & $(0.10)$ & $(0.11)$ \\
\hline Restrictions*Fixed Exchange Rate & & & 0.02 & 0.02 \\
\hline & & & $(0.03)$ & $(0.03)$ \\
\hline Restrictions*Post-Maas. & & & $0.41 *$ & 0.41 \\
\hline & & & $(0.07)$ & $(0.24)$ \\
\hline Trade & & & 0.003 & 0.003 \\
\hline & & & $(0.001)$ & $(0.002)$ \\
\hline Trade*CBI & & & $-0.02 *$ & $-0.02 *$ \\
\hline & & & $(0.006)$ & $(0.007)$ \\
\hline Trade*Fixed Exchange Rate & & & 0.004 & 0.004 \\
\hline
\end{tabular}




\begin{tabular}{|c|c|c|c|c|}
\hline Trade*Post-Maastricht & & & $\begin{array}{c}(0.002) \\
-0.002 \\
(0.002)\end{array}$ & $\begin{array}{c}(0.002) \\
-0.002 \\
(0.004)\end{array}$ \\
\hline R-Squared & 0.26 & 0.30 & 0.39 & 0.39 \\
\hline MSE & 0.2750 & 0.2697 & 0.2646 & 0.2646 \\
\hline \multicolumn{5}{|l|}{ Tests of Joint Significance } \\
\hline Model & $56.28 *$ & $54.10 *$ & $137.42 *$ & $3.97 *$ \\
\hline Minimum Winning Coalition & & & $3.38^{*}$ & 2.19 \\
\hline Minority/Oversize Coalition & & & 1.80 & 1.48 \\
\hline Central Bank Independence & & & $31.21 *$ & 1.73 \\
\hline Fixed Exchange Rate & & & $3.13^{*}$ & 1.71 \\
\hline Post-Maastricht & & & $13.27 *$ & 1.00 \\
\hline Restrictions & & & $11.30 *$ & 2.23 \\
\hline Trade & & & $16.19 *$ & 2.20 \\
\hline
\end{tabular}

$\mathrm{N}=193$ for all models.

Models I-III estimated via OLS Regression with Robust Standard Errors. Model IV estimated via

OLS Regression.

$* \mathrm{p}<0.05$

Tests of Joint Significance are for combinations of the following variables:

Model: all variables;

Minimum Winning Coalition: Minimum Winning Coalition, MWC*CBI, MWC*Fixed

Exchange Rate, MWC*CBI*Fixed Exchange Rate, MWC*CBI*Post-Maastricht;

Minority/Oversize Coalition: Minority/Oversize Coalition, Min/Over*CBI, Min/Over*Fixed

Exchange Rate, Min/Over*Post-Maastricht, Min/Over*CBI*Fixed Exchange Rate;

Central Bank Independence: CBI, MWC*CBI, MWC*CBI*Fixed Exchange Rate,

Min/Over*CBI, Min/Over*CBI*Fixed Exchange Rate, CBI*Fixed Exchange Rate, CBI*Post-

Maastricht, $\mathrm{CBI}^{*}$ Restrictions, $\mathrm{CBI}{ }^{*}$ Trade;

Fixed Exchange Rate: Fixed Exchange Rate, MWC*Fixed Exchange Rate, MWC*CBI*Fixed

Exchange Rate, Min/Over*Fixed Exchange Rate, Min/Over*CBI*Fixed Exchange Rate,

CBI*Fixed Exchange Rate, Fixed Exchange Rate*Restrictions, Fixed Exchange Rate*Trade;

Post-Maastricht: Post-Maastricht, MWC*CBI*Post-Maastricht, Min/Over*Post-Maastricht,

CBI*Post-Maastricht, Post-Maastricht*Restrictions, Trade*Post-Maastricht; 
Restrictions: Restrictions, CBI*Restrictions, Fixed Exchange Rate*Restrictions, PostMaastricht*Restrictions;

Trade: Restrictions, CBI*Trade, Fixed Exchange Rate*Trade, Post-Maastricht*Trade. 


\begin{tabular}{|c|c|c|}
\hline \multicolumn{3}{|c|}{ Table 3: Institutional Reform in the Industrial Democracies Since 1979} \\
\hline Country & Year & Reform to Electoral System, Central Bank, Exchange Rate \\
\hline Australia & 1983 & Adopt Floating Exchange Rate \\
\hline Austria & 1996 & Join European Monetary System, Post-Maastricht \\
\hline \multirow[t]{3}{*}{ Belgium } & 1979 & Join European Monetary System \\
\hline & 1991 & Sign Maastricht Treaty \\
\hline & 1993 & Grant Central Bank More Independence \\
\hline \multicolumn{3}{|r|}{ e } \\
\hline \multirow[t]{2}{*}{ Denmark } & 1979 & Join European Monetary System \\
\hline & 1991 & Sign Maastricht Treaty (Eventually opt-out of Euro) \\
\hline \multirow[t]{2}{*}{ Finland } & 1996 & Join European Monetary System, Post-Maastricht \\
\hline & 1998 & Grant Central bank Independence \\
\hline \multirow[t]{3}{*}{ France } & 1979 & Join European Monetary System \\
\hline & 1991 & Sign Maastricht Treaty \\
\hline & 1993 & Grant Central Bank Independence \\
\hline \multirow[t]{2}{*}{ Germany } & 1979 & Join European Monetary System \\
\hline & 1991 & Sign Maastricht Treaty \\
\hline \multirow[t]{3}{*}{ Ireland } & 1979 & Join European Monetary System \\
\hline & 1991 & Sign Maastricht Treaty \\
\hline & 1998 & Grant Central Bank Independence \\
\hline \multirow[t]{7}{*}{ Italy } & 1979 & Join European Monetary System \\
\hline & 1981 & Grant Central Bank More Independence (Divorce) \\
\hline & 1991 & Sign Maastricht Treaty \\
\hline & 1992 & Leave European Monetary System \\
\hline & 1992 & Grant Central Bank Independence \\
\hline & 1994 & Electoral System Reform \\
\hline & 1996 & Return to European Monetary System \\
\hline \multirow[t]{2}{*}{ Japan } & 1993 & Electoral System Reform \\
\hline & 1998 & Grant Central Bank Independence \\
\hline \multirow[t]{3}{*}{ New Zealand } & 1985 & Adopt Floating Exchange Rate \\
\hline & 1990 & Grant Central Bank Independence \\
\hline & 1992 & Electoral System Reform \\
\hline \multirow[t]{2}{*}{ Netherlands } & 1979 & Join European Monetary System \\
\hline & 1991 & Sign Maastricht Treaty \\
\hline \multirow[t]{2}{*}{ Norway } & 1992 & Adopt Floating Exchange Rate \\
\hline & 1994 & Adopt Fixed Exchange Rate ${ }^{61}$ \\
\hline \multirow[t]{2}{*}{ Sweden } & 1996 & Join European Monetary System, Post-Maastricht \\
\hline & 1998 & Grant Central Bank Independence \\
\hline \multirow{3}{*}{ United Kingdom } & 1990 & Join European Monetary System \\
\hline & 1992 & Leave European Monetary System \\
\hline & 1997 & Grant Central Bank Independence \\
\hline
\end{tabular}

${ }^{61}$ In 1994, Norway decided to manage the krone vis-à-vis the ECU. While the monetary policy guidelines stated that the monetary policy would be aimed at keeping the krone stable against the ECU, no commitment was made to defend a specific parity. 


\begin{tabular}{|c|c|c|c|c|c|c|c|c|}
\hline Country & Period & Trade & $\begin{array}{l}\text { Cross- } \\
\text { Border } \\
\text { Restric. }\end{array}$ & CBI & $\begin{array}{l}\text { Exch. } \\
\text { Rate } \\
\text { Reg. }\end{array}$ & $\begin{array}{l}\text { Cab. } \\
\text { Type }\end{array}$ & $\begin{array}{l}\text { E(Cabinet Durability) } \\
\text { in 1994-96 }\end{array}$ & Difference \\
\hline \multirow[t]{2}{*}{ U.K. } & $1979-1981$ & 52.8 & 11.2 & 0.27 & Float & $\mathrm{S}$ & $0.66(0.53,0.81)$ & \multirow[t]{2}{*}{ STromo } \\
\hline & 1994-1996 & 57.3 & 13 & 0.27 & Float & $\mathrm{S}$ & $0.66(0.53,0.81)$ & \\
\hline \multirow[t]{2}{*}{ Belgium } & 1979-1981 & 119.9 & 10 & 0.17 & Float & Mix & $0.53(0.30,0.75)$ & \multirow[b]{2}{*}{0.07} \\
\hline & 1994-1996 & 128.9 & 13.8 & 0.47 & EMU & Mix & $0.60(0.29,0.85)$ & \\
\hline \multirow[t]{2}{*}{ France } & 1979-1981 & 44.0 & 11 & 0.24 & Float & Mix & $0.56(0.42,0.70)$ & \multirow[b]{2}{*}{0.07} \\
\hline & 1994-1996 & 44.6 & 13 & 0.56 & EMU & Mix & $0.63(0.34,0.93)$ & \\
\hline \multirow[t]{2}{*}{ Germany } & 1979-1981 & 53.2 & 13.7 & 0.69 & Float & $\mathrm{M}$ & $0.84(0.67,1.06)$ & \multirow[b]{2}{*}{0.16} \\
\hline & 1994-1996 & 46.6 & 14 & 0.69 & EMU & $\mathrm{M}$ & $1.00(0.73,1.29)$ & \\
\hline \multirow[t]{2}{*}{ Italy } & 1979-1981 & 47.7 & 10.5 & 0.25 & Float & $\mathrm{C}$ & $0.23(0.15,0.30)$ & \multirow[b]{2}{*}{$0.72 *$} \\
\hline & 1994-1996 & 48.2 & 14 & 0.47 & EMU & $\mathrm{C}$ & $0.95(0.54,1.34)$ & \\
\hline \multirow[t]{2}{*}{ Neth'land } & 1979-1981 & 102.9 & 13 & 0.42 & Float & Mix & $0.40(0.30,0.52)$ & \multirow[b]{2}{*}{$0.52 *$} \\
\hline & 1994-1996 & 98.8 & 14 & 0.42 & EMU & Mix & $0.92(0.74,1.08)$ & \\
\hline \multirow[t]{2}{*}{ Norway } & 1979-1981 & 79.1 & 8.5 & 0.17 & Fix & $\mathrm{C}$ & $0.88(0.73,1.07)$ & \multirow[b]{2}{*}{0} \\
\hline & 1994-1996 & 71.1 & 13.5 & 0.17 & Fix & $\mathrm{C}$ & $0.88(0.73,1.07)$ & \\
\hline \multirow[t]{2}{*}{ Sweden } & $1979-1981$ & 60.7 & 10.7 & 0.29 & Fix & $\mathrm{C}$ & $0.89(0.79,0.98)$ & \multirow[b]{2}{*}{0.02} \\
\hline & 1994-1996 & 72.4 & 13 & 0.29 & EMU & $\mathrm{C}$ & $0.91(0.59,1.28)$ & \\
\hline \multirow[t]{2}{*}{ Canada } & 1979-1981 & 53.9 & 12 & 0.45 & Float & Mix & $0.51(0.39,0.63)$ & \multirow[b]{2}{*}{0} \\
\hline & 1994-1996 & 72.4 & 14 & 0.45 & Float & Mix & $0.51(0.39,0.63)$ & \\
\hline \multirow[t]{2}{*}{ Japan } & $1979-1981$ & 27.0 & 10.2 & 0.18 & Float & Mix & $0.55(0.44,0.64)$ & \multirow[b]{2}{*}{-0.09} \\
\hline & 1994-1996 & 17.7 & 11 & 0.18 & Float & Mix & $0.46(0.34,0.63)$ & \\
\hline \multirow[t]{2}{*}{ Denmark } & 1979-1981 & 68.4 & 10 & 0.44 & Float & $\mathrm{C}$ & $0.31(0.17,0.44)$ & \multirow[b]{2}{*}{$0.48 *$} \\
\hline & 1994-1996 & 66.1 & 14 & 0.44 & EMU & $\mathrm{C}$ & $0.79(0.50,1.05)$ & \\
\hline \multirow[t]{2}{*}{ Finland } & 1979-1981 & 64.8 & 10.5 & 0.28 & Fix & $\mathrm{C}$ & $0.90(0.81,1.01)$ & \multirow[b]{2}{*}{$0.43 *$} \\
\hline & 1994-1996 & 66.7 & 14 & 0.28 & EMU & $\mathrm{C}$ & $1.33(0.96,1.79)$ & \\
\hline \multirow[t]{2}{*}{ Ireland } & 1979-1981 & 108.9 & 10.5 & 0.44 & Float & Mix & $0.27(0.10,0.43)$ & \multirow[b]{2}{*}{$0.54 *$} \\
\hline & 1994-1996 & 132.6 & 13.8 & 0.44 & EMU & Mix & $0.81(0.52,1.09)$ & \\
\hline \multirow[t]{2}{*}{ Australia } & 1979-1981 & 34.0 & 8.2 & 0.36 & Fix & Mix & $0.74(0.66,0.82)$ & \multirow[b]{2}{*}{-0.01} \\
\hline & 1994-1996 & 39.9 & 11.5 & 0.36 & Float & Mix & $0.73(0.65,0.80)$ & \\
\hline New & 1979-1981 & 62.1 & 7.3 & 0.24 & Fix & $\mathrm{S}$ & $0.99(0.78,1.15)$ & \\
\hline Zealand & 1994-1996 & 58.7 & 13.2 & 0.42 & Float & $\mathrm{M}$ & $0.73(0.63,0.83)$ & $-0.26^{*}$ \\
\hline Austria & 1979-1981 & 73.26 & 11.5 & 0.61 & Fix & Mix & $0.49(0.37,0.64)$ & \\
\hline & 1994-1996 & 77.9 & 12.8 & 0.61 & EMU & Mix & $0.37(-0.87,1.49)$ & -0.12 \\
\hline
\end{tabular}

$* \mathrm{p}<0.05$

90\% Confidence Intervals calculated using procedures developed by King, Tomz, and Wittenberg

(2000).

CBI: Ranking of Central Bank Independence Based on Cukierman, Webb, Neyapti (1992).

Exchange Rate Regime:

Float=Floating Exchange Rate 
Fix=Fixed Exchange Rate

EMU=participation in the E.M.S. after January 1993. For Austria, Finland, and Sweden, participation starts in January 1996. Italy rejoins in 1996.

\section{Cabinet Type:}

$\mathrm{S}=$ single-party majority governments.

$\mathrm{M}=$ minimum winning coalitions.

$\mathrm{C}=$ minority and oversize coalition governments.

Mix = sample based proportion of different government types. 
Figure 1: Effect of Central Bank Independence on Expected Cabinet Durability for Different Government Types, Floating Exchange Rate

○ SPM; No Commitment $\quad \square$ MWC; No Commitment

$\triangle$ MIN/OVER; No Commitment

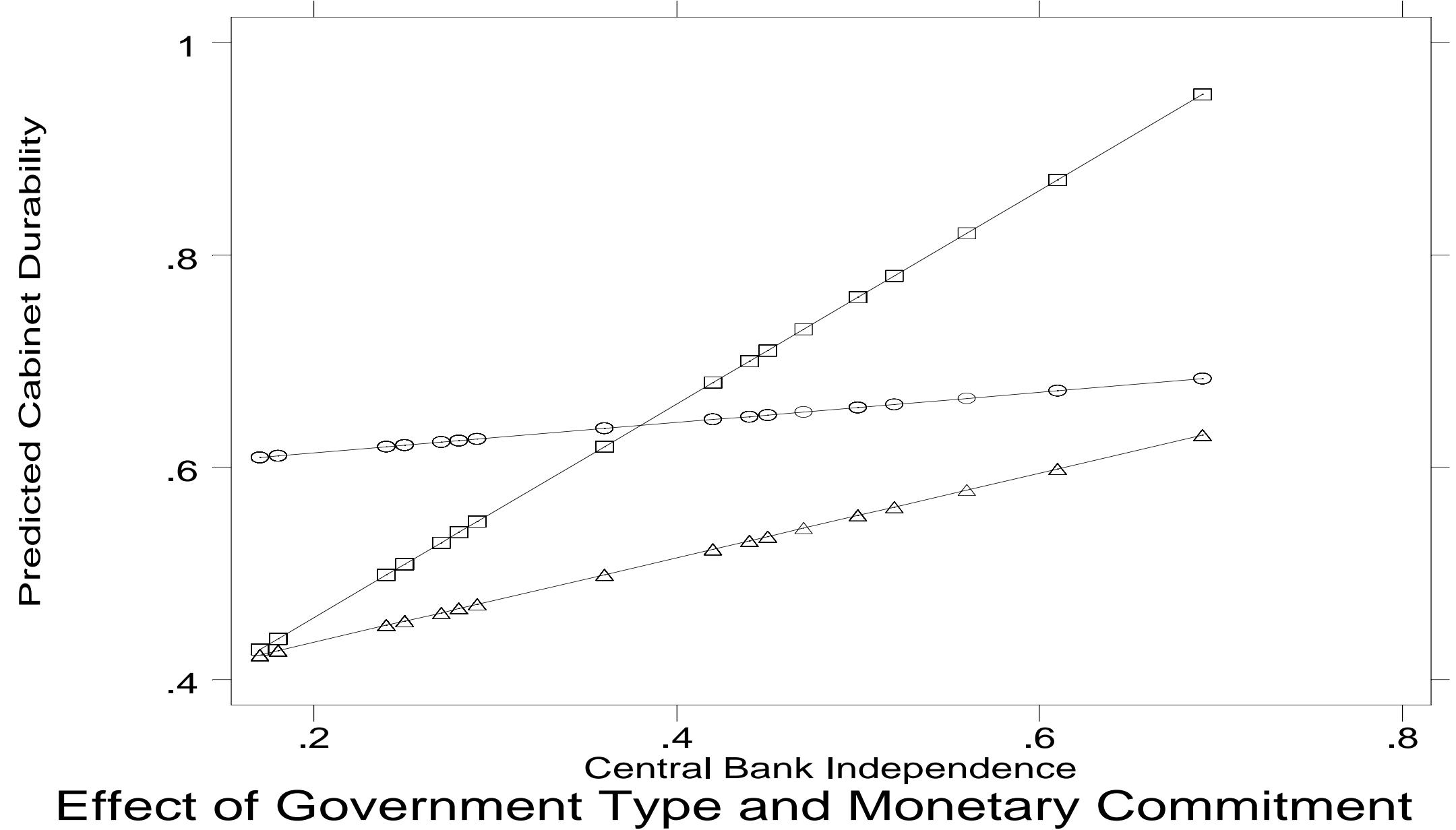


Figure 2: Effect of Central Bank Independence on Expected Cabinet Durability for Different Government Types, Fixed Exchange Rate

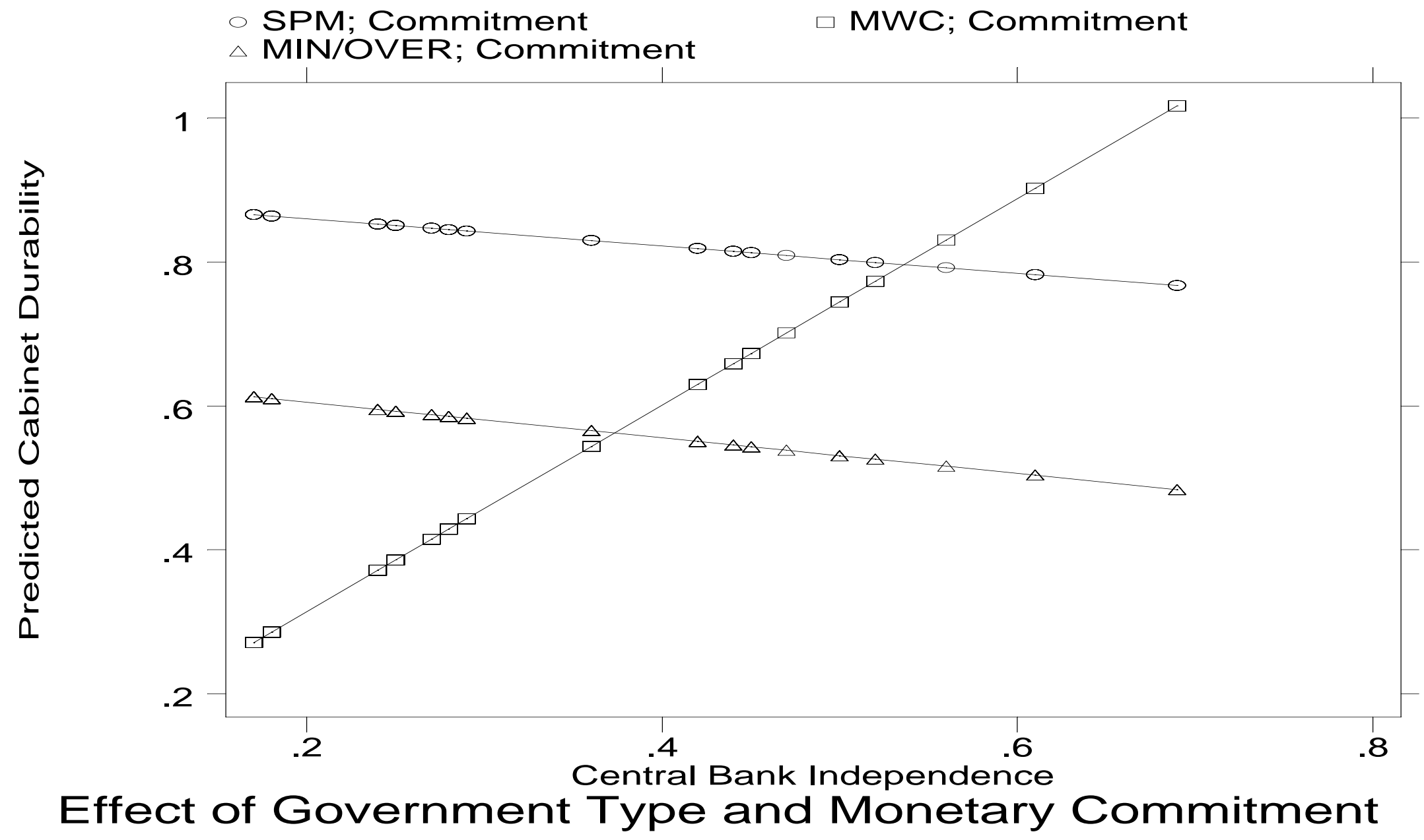

